\title{
The quality of subgroup analyses in chronic pain randomized controlled trials: a methodological review
}

\author{
Mahmood AminiLari ${ }^{1,2}$, Vahid Ashoorian ${ }^{2}$, Alexa Caldwell ${ }^{3}$, Yasir Rahman ${ }^{1,2}$, Robby Nieuwlaat ${ }^{1}$, \\ Jason W. Busse ${ }^{1,2,5}$, and Lawrence Mbuagbaw ${ }^{1,4}$
}

'Department of Health Research Methods, Evidence, and Impact, McMaster University, Hamilton, Ontario, Canada

${ }^{2}$ Michael G. DeGroote Institute for Pain Research and Care, McMaster University, Hamilton, Ontario, Canada

${ }^{3}$ Michael G. DeGroote School of Medicine, McMaster University, Hamilton, Ontario, Canada

${ }^{4}$ Biostatistics Unit, St Joseph's Healthcare Hamilton, Hamilton, Ontario, Canada

${ }^{5}$ Department of Anesthesia, McMaster University, Hamilton, Ontario, Canada

Received September 28, 2020

Revised November 16, 2020

Accepted November 25, 2020

Handling Editor: Hyun Kang

\section{Correspondence}

Mahmood AminiLari

Department of Health Research

Methods, Evidence and Impact (HEI),

Faculty of Health Sciences, McMaster

University, 1280 Main Street West, $2 C$

Area, Hamilton, ON L8S 4K1, Canada

Tel: +1-905-554-7283

Fax: +1-905-526-1289

E-mail: aminilam@mcmaster.ca
The quality of subgroup analyses (SGAs) in chronic non-cancer pain trials is uncertain. The purpose of this study was to address this issue. We conducted a comprehensive search in MEDLINE and EMBASE from January 2012 to September 2018 to identify eligible trials. Two pairs of reviewers assessed the quality of the SGAs and the credibility of subgroup claims using the 10 criteria developed by Sun et al. in 2012. The associations between the quality of the SGAs and the studies' characteristics including risk of bias, funding sources, sample size, and the latest impact factor, were assessed using multivariable logistic regression. Our search retrieved 3,401 articles of which 66 were eligible. The total number of SGAs was 177 of which 52 (29.4\%) made a subgroup claim. Of these, only 15 (8.5\%) were evaluated as being of high quality. Among the 30 SGAs that claimed subgroup effects using an appropriate method of performing interaction tests, the credibility of only 5 were assessed as high. None of the subgroup claims met all the credibility criteria. No significant association was found between the quality of SGAs and the studies' characteristics. The quality of the SGAs performed in chronic pain trials was poor. To enhance the quality of SGAs, scholars should consider the developed criteria when designing and conducting trials, particularly those which need to be specified a priori.

Key Words: Bias; Chronic Pain; Logistic Models; MEDLINE; Methods; Pain; Research Design; Uncertainty.

\section{INTRODUCTION}

Chronic non-cancer pain (CNCP) refers to pain not due to cancer lasting more than three months [1]. CNCP is a disabling health condition which is highly prevalent and affects approximately $28 \%$ of people globally [2]. Randomized controlled trials (RCTs) aim to provide reliable evi- dence on the efficacy and adverse effects of interventions in general patient populations [3]. However, clinical decisions often depend on individual patient characteristics. Those conducting trials often perform subgroup analyses (SGAs), defined as evaluating the treatment effects in specific subgroups of patients or interventions, to indicate whether the observed treatment effect is altered by base- (c) This is an open-access article distributed under the terms of the Creative Commons Attribution Non-Commercial License (http://creativecommons.org/licenses/by-nc/4.0/), which permits unrestricted non-commercial use, distribution, and reproduction in any medium, provided the original work is properly cited.

(C) The Korean Pain Society, 2021
Author contributions: Mahmood AminiLari: Methodology; Vahid Ashoorian: Investigation; Alexa Caldwell: Investigation; Yasir Rahman: Data curation; Robby Nieuwlaat: Supervision; Jason W. Busse: Proposal preparation, Analysis plan; Lawrence Mbuagbaw: Supervision. 
line characteristics of the study population [4,5]. SGAs thus play a significant role in suggesting the appropriateness of an intervention for a specific patient population and addresses the clinical need for individually based guidelines. They can also inform future studies by determining whether specific baseline prognostic factors may impact outcome measures of interest. However, the practical potential of SGAs can only be realized if an SGA is rigorous in its design and interpretation, as its results may be misleading if incorrectly performed [6].

Numerous criteria have been developed to evaluate the quality of SGAs. Firstly, it is necessary to evaluate if the treatment effect varies across subgroup categories. Since appropriate statistical tests can only identify the extent to which chance explains a study's results and not other factors, performing SGAs without testing for interactions is not a valid technique. More importantly, the lack of a priori subgroup hypotheses, and the direction of these interactions can inflate type I error by allowing for multiple hypotheses testing and enhancing the chance of producing spurious subgroup effects $[6,7]$.

Within the literature, it has been found that subgroup claims are often subsequently shown to be incorrect, and that the credibility of subgroup effects is usually low [4]. Notably, a methodological review conducted in the field of chronic back pain found the credibility of subgroup claims to be low [8].

Within the CNCP field, many RCTs have performed SGAs to assess the treatment effects across different subgroups. However, the quality of these analyses and the credibility of the claimed subgroup effects are relatively unknown [8]. There are explicit criteria to help determine the credibility of subgroup effects $[4,9,10]$. Applying these criteria to CNCP trials, that report SGAs, can help inform the quality of SGAs in this field.

As such, the primary objective of this review was to describe the quality and the credibility of the SGAs conducted in CNCP trials through evaluating their satisfaction of the criteria developed by Sun et al. [4] for assessing the validity of SGAs. Our secondary objective was to explore the associations between studies' characteristics, including risk of bias, funding sources, sample size, and the latest impact factor with the quality of SGAs.

\section{MATERIALS AND METHODS}

\section{Inclusion criteria}

In this study, we included RCTs that were carried out in humans for the management of CNCP. We did not apply restrictions on the basis of study design (parallel, cross- over, factorial), number of trial arms, unit of randomization, type of study, study sample size, or category of outcome. To meet inclusion criteria, the RCTs needed to have included one or more SGAs, with or without a subgroup claim. Conference abstracts and publications which were not in English were excluded. The included studies were indexed in MEDLINE and EMBASE from January 2012 to September 2018.

\section{Search strategy}

An extensive and predefined search strategy (Appendix 1) of MEDLINE and EMBASE was conducted from January 2012 to September 2018, using the OVID platform. The strategy's search terms included both MeSH headings and free texts for "subgroup analysis", "chronic pain", " neuropathic pain ", "intervention", "treatment", "management", and "randomized controlled trials".

\section{Selection of the eligible studies}

Two reviewers (MA and VA), independently and in duplicate, screened titles, and abstracts in the field of pain management to detect citations that were RCTs in humans that performed at least one SGA. For the purposes of this study, we defined an SGA as a statistical analysis that explored whether the effects of an intervention differed according to a sub-group variable. Subsequently, the reviewers, independently and in duplicate, screened the full text of all potentially eligible trials to determine if they met the study's inclusion criteria such as reporting at least one SGA, claiming a subgroup effect using an interaction test, reporting a $P$ value for a subgroup effect, and the magnitude of difference in the effect between patient subgroups.

\section{Data extraction and management}

The data extraction form was created and developed by the principal investigator. At the stage of full text screening, the principal investigator, along with two other reviewers trained in research methodology (MA\&VA-MA\&YR), extracted information independently and in duplicate from the eligible RCTs. The extracted data included 1) the year of publication, 2) the funding sources, 3) the journal name and latest impact factor (mostly the Thomson Reuters Impact Factor), 4) the trial design, 5) the trial type, 6) the type of participants, 7) the type of intervention and its comparator, 8) the primary outcome(s) and secondary outcome(s), 9) the follow-up duration, 10) the sample size, and 11) the treatment effect for the primary outcome prior to performing the SGA. In the studies that were published as posthoc analyses of trials, we used additional resources cited 
in the included studies, such as published or registered protocols and main trials, to make a more rigorous judgment regarding the quality of the SGAs and the risk of bias assessments.

\section{Quality of SGAs}

Two pairs of reviewers recorded the number of SGAs performed in each RCT. We assessed the quality and credibility of the SGAs reported using the 10 criteria mentioned above [4]. We assessed the quality of SGAs when the trial performed an SGA but concluded a negative result, and when the trial performed an SGA using an interaction test and claimed a subgroup effect. Due to the various conditions encountered, the following guidelines were developed for the number of criteria considered to evaluate the SGAs:

1) When the trial performed an interaction test and the result was positive (subgroup effect was reported or claimed), all 10 criteria were assessed (credibility).

2) When the trial performed an interaction test and the result was negative (no subgroup effect claimed), 6 criteria were assessed (criteria \# 1 to \#5 and \#7 were applicable).

3) When the trial did not perform an interaction test but reported a positive result (subgroup effect was reported, or the authors reported that the effect appeared larger in one subgroup than another, but acknowledged the fact that they didn't have the power to detect an interaction effect, and therefore these results were considered to be hypothesis generating), 8 criteria were assessed (criteria $\# 5$ and $\# 6$ were not applicable).

4) When the trial did not perform an interaction test and reported a negative result (no subgroup effect), only the first 4 criteria were assessed.

It should be noted that the first item reflects "credibility", and the next three items reflect the "quality" of SGAs. The quality of all SGAs reported in each study was coded based on the detailed instructions established by Sun et al. [4], which were used in previous studies (Appendix 2). Each criterion was scored as 1 if the answer to the item was "yes" (criterion met) and 0 if the answer was "no" (criterion not met). We only assessed the SGA for the pain-related primary outcome and the last follow-up time. If pain was not the primary outcome, we considered the SGA for the primary outcome in addition to the SGA for the most relevant outcome to pain among the secondary outcomes.

Depending on the number of criteria assessed, we scored each SGA between 0 to 10,0 to 8,0 to 6 , or 0 to 4 . We conventionally classified the quality of each SGA based on the proportion of criteria met as high-quality $(60 \%$ or more) or low quality (less than $60 \%$ ).

We specifically assessed the credibility of SGAs for those studies which claimed a subgroup effect after performing an interaction test.

\section{Risk of bias}

Reviewers assessed the risk of bias for included RCTs, independently and in duplicate, using a modified Cochrane risk of bias instrument $[11,12]$. All disagreements in different stages were resolved by reaching a consensus or consulting with a third reviewer (LM).

\section{Data analysis}

We used descriptive statistics to summarize and calculate the proportion of trials reporting at least one SGA or claiming a subgroup effect. We also calculated the proportion of SGAs (those which claimed a subgroup effect) meeting each credibility criterion and the number of criteria met by each SGA.

The normality and homogeneity of variance assumptions for continuous outcomes (e.g., functional scores) was verified using the Shapiro-Wilk test and Levene's test, respectively. We performed multivariable linear regression models to assess the potential associations between the quality of the SGAs (as a continues variable) and prespecified study characteristics including the risk of bias (low-risk vs. high-risk based on the overall judgment of the reviewers), funding sources (industry and non-industry), sample size (small vs. large), and the latest impact factor (as a continues variable). A theory-driven approach was used to build the final multivariable regression model and select the most influential predictor variables. We dichotomized the studies' sample sizes based on the median of this variable into two groups: above and below the median.

To control for the impact of potential multicollinearity issues between the covariates, we calculated the variance inflation factor (VIF) of all variables included in the final models. A VIF of 10 or above (a tolerance of 0.1 ) was considered as multicollinearity.

To run the regression models, since some of the studies had performed more than one SGA with the same approach to analyzing subgroup effects, we included only one SGA with the highest score in the quality assessment from each study in the regression model. Through applying this approach we limited our analysis to including 66 SGAs, which was equal to the number of studies included. The goodness of fit for the models was also evaluated using the Hosmer-Lemeshow test [13]. Agreement between reviewers regarding: 1) the quality of SGAs, 2) the use of 


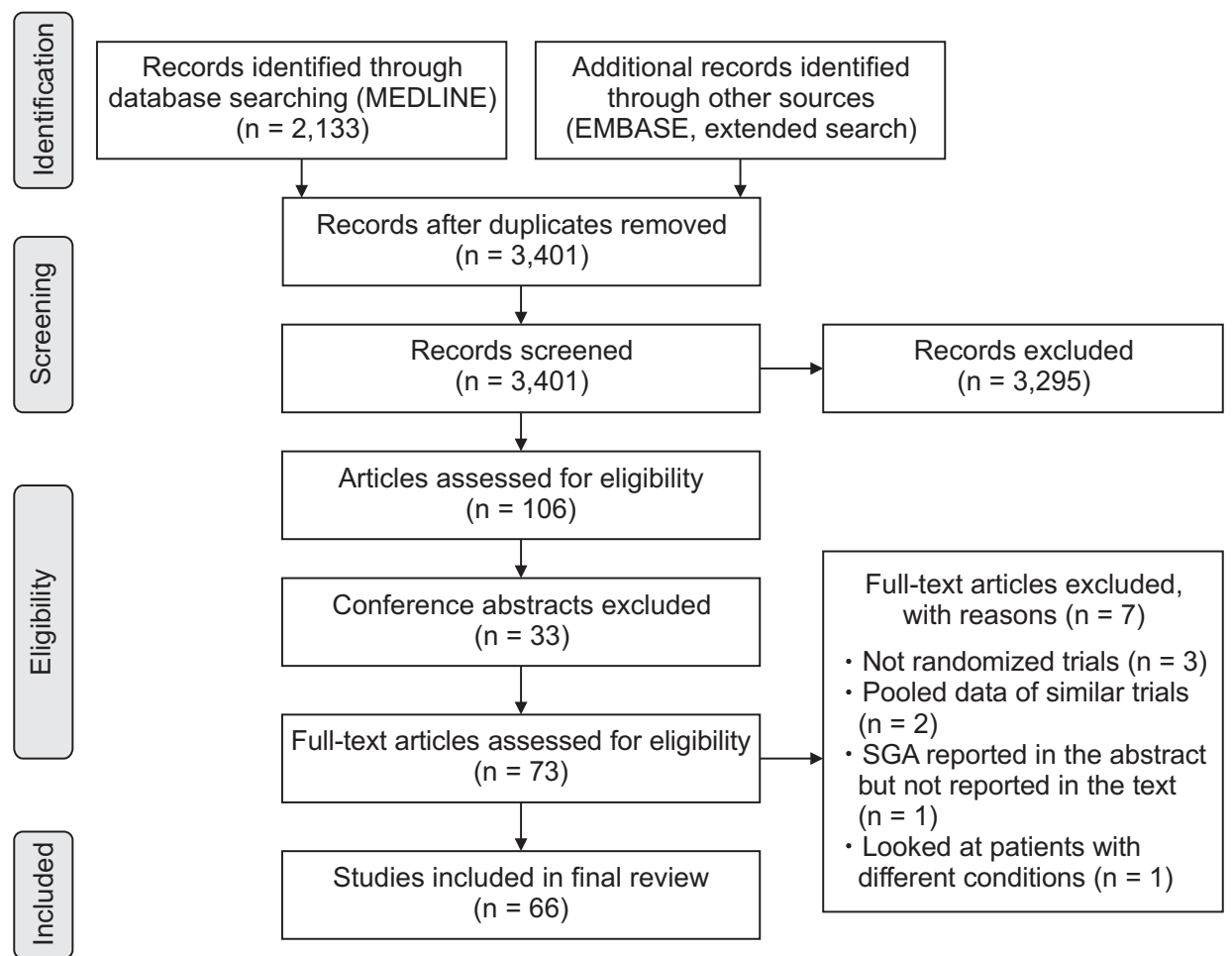

Fig. 1. Study flow diagram. SGA: subgroup analysis.

the interaction test, and 3) the risk of bias assessment was calculated using the Cohen's Kappa statistic. We considered the kappa values of $0-0.20,0.21-0.40,0.41-0.60$, and 0.61-0.80 as indicating slight, fair, moderate, and substantial agreement, respectively. Values of more than 0.80 were regarded as almost perfect agreement [14]. All analyses were performed using SPSS software version 24 (IBM Co., Armonk, NY).

\section{Sample size}

To perform the linear regression analysis, we calculated the total number of RCTs that would need to be included. According to Harris and Quade [15], as the rule of thumb for multivariable linear regression analyses, for five or less predictors, the number of subjects should exceed the number of independent variables by 50 . For equations involving six or more predictors, an absolute number of 10 subjects per predictor is recommended. Based on these recommendations, a total sample size of at least 60 RCTs was calculated to be included in this study. Considering 4 independent variables for running linear regression models, this study, with 66 RCTs, has sufficient power to produce reliable results.

\section{RESULTS}

Two reviewers screened 3,401 titles and abstracts. Of these,
Table 1. Characteristics of 66 included studies

\begin{tabular}{llc}
\hline \multicolumn{1}{c}{ Study characteristic } & \multicolumn{1}{c}{ Category } & Frequency \\
\hline Trial type & Single center & $30(45.5)$ \\
& Multi-center & $36(54.5)$ \\
Source of funding & Industry & $37(56.1)$ \\
& Non-industry & $25(37.9)$ \\
& Both & $1(1.5)$ \\
& Not reported & $3(4.5)$ \\
Primary outcome (pain) & Yes & $43(65.2)$ \\
& No & $23(34.8)$ \\
Post-hoc analysis & Yes & $37(56.1)$ \\
& No & $29(43.9)$ \\
Treatment effect of primary outcome & Positive & $24(36.4)$ \\
(main trial) & Negative & $42(63.6)$ \\
Risk of bias & High & \\
& Low & $38(57.6)$ \\
& & $28(42.4)$ \\
\hline
\end{tabular}

Values are presented as number (\%).

aHigh risk of bias: risk of bias evaluated as "High" independently and in duplicate, using a modified Cochrane risk of bias instrument, "Low risk of bias: risk of bias evaluated as "Low" independently and in duplicate, using a modified Cochrane risk of bias instrument.

106 publications were potentially identified as eligible. However, 33 articles were conference abstracts, and were thus excluded (Fig. 1). The full texts of the remaining 73 studies were retrieved and screened. Sixty-six RCTs were included in the final review, based on the study's eligibility criteria. The descriptions of included studies are reported in Table 1, Appendix 3. 
The inter-rater agreements (Kappa values) for the assessment of the quality of SGAs, the determinant of subgroup claims, and the risk of bias assessment were $0.72(95 \%$ confidence interval [CI]: 0.57-0.87), 0.76 (95\% CI: 0.60-0.92), and 0.70 (95\% CI: 0.51-0.89), respectively, representing substantial agreement.

Thirty seven out of 66 studies (56.1\%) were industryfunded, and 36 (54.5\%) were multi-center trials. Within the 66 included studies in the final review, the total number of SGAs reported was 177 (range $=51$ ), and $68.8 \%$ of the included studies performed only one SGA. Of these, $52(29.4 \%)$ claimed a subgroup effect. Thirty-two studies $(48.5 \%)$ performed SGAs using a statistical test for interaction, and the remaining 34 studies (51.5\%) performed statistical tests within individual subgroups and compared the results without an interaction test. The frequency of the SGAs, based on the performance of an interaction test (yes or no), is presented in Table 2. Among all SGAs, the quality of only $15(8.5 \%)$ was evaluated as high (score $\geq 6$

Table 2. Frequency of SGAs categorized based on the result, and performing interaction test ${ }^{\mathrm{a}}$

\begin{tabular}{cccc}
\hline $\begin{array}{c}\text { Test of interaction } \\
\text { (yes or no)/SGA result } \\
\text { (positive or negative) }\end{array}$ & Frequency & $\begin{array}{c}\text { Quality of } \\
\text { SGAs }\end{array}$ & Frequency \\
\hline Yes/Positive & $30(16.9)$ & High & $5(16.7)$ \\
Yes/Negative & $96(54.2)$ & Low & $25(83.3)$ \\
No/Positive & $22(12.4)$ & Low & $3(3.1)$ \\
No/Negative & $29(16.4)$ & High & $1(4.5)$ \\
& & Low & $21(95.5)$ \\
& & & $23(20.7)$ \\
\hline
\end{tabular}

Values are presented as number (\%).

SGAs: subgroup analyses.

${ }^{a}$ The 117 SGAs are categorized based on performing an interaction test (yes or no) and the SGA result (positive or negative). out of 10), and none of the SGAs met all the credibility criteria.

Table 2 also presents the frequency of the SGAs that reported subgroup interactions, which were either positive or negative. Among the 30 (16.9\%) SGAs that reported positive results (claimed subgroup effects) using an appropriate method of performing interaction tests, the credibility of only 5 of these SGAs was assessed as high.

Table 3 further indicates the proportion of the abovementioned 30 SGAs that met each credibility criteria. In 3 SGAs, the subgroup variable was not a characteristic measured at baseline. Additionally, only 1 SGA reported the subgroup variable as a stratification factor at randomization, and only 11 SGAs clearly indicated an a priori hypothesis regarding a subgroup effect. Of the 30 claims, only $5(16.7 \%)$ correctly pre-specified the direction of the subgroup effect.

\section{Statistical analyses}

\section{1) Regression analyses of study variables}

We did not find any significant associations using univariate and multivariable regression analyses evaluating the association between the quality of SGAs and the study characteristics (risk of bias, funding sources, sample size, and latest impact factor). The summary of the analyses is presented in Table 4.

We assessed the goodness of fit for the final model using the Homer and Lemeshow test. The statistical analysis showed that the Chi-square of 2.241 with 8 degrees of freedom was not significant $(P$ value $=0.973)$. Therefore, the null hypothesis (H0: The model is appropriate) was rejected and this indicated that the model is appropriate.

Table 3. Proportion of 30 subgroup analyses claiming a subgroup effect which met each criterion

\begin{tabular}{|c|c|c|}
\hline Criteria & No (criterion not met) & Yes (criterion met) \\
\hline 1. Is the subgroup variable a characteristic measured at baseline? & $3(10.0)$ & $27(90.0)$ \\
\hline 2. Was the subgroup variable a stratification factor at randomisation? & $29(96.7)$ & $1(3.3)$ \\
\hline 3. Was the hypothesis specified a priori? & $19(63.3)$ & $11(36.7)$ \\
\hline 4. Was the subgroup analysis one of small number of subgroup hypotheses tested $(\leq 5)$ ? & $10(33.3)$ & $20(66.7)$ \\
\hline 5. Was the test of interaction significant (interaction $P<0.05$ )? & 0 & $30(100)$ \\
\hline 6. Was the significant interaction effect independent, if there were multiple significant interactions? & $16(53.3)$ & $14(46.7)$ \\
\hline 7. Was the direction of subgroup effect correctly pre-specified? & $25(83.3)$ & $5(16.7)$ \\
\hline 8. Was the subgroup effect consistent with evidence from previous studies? & $20(66.7)$ & $10(33.3)$ \\
\hline 9. Was the subgroup effect consistent across related outcomes? & $20(66.7)$ & $10(33.3)$ \\
\hline $\begin{array}{l}\text { 10. Was there indirect evidence to support the apparent subgroup effect (biological rationale, laboratory } \\
\text { tests, animal studies)? }\end{array}$ & $28(93.3)$ & $2(6.7)$ \\
\hline
\end{tabular}

Values are presented as number (\%). 
Table 4. Association between quality of SGAs with studies' characteristics using multiple linear regression models

\begin{tabular}{lccccc}
\hline \multirow{2}{*}{ Variable } & \multicolumn{2}{c}{ Univariable analysis } & & & Multivariable analysis \\
\cline { 2 - 3 } \cline { 5 - 6 } & $\mathrm{B}(95 \% \mathrm{Cl})$ & $P$ value & $\mathrm{B}(95 \% \mathrm{Cl})$ & \\
\hline Risk of bias & $0.33(-0.24,0.91)$ & 0.258 & $0.16(-0.45,0.78)$ & 0.591 \\
Source of funding & $-0.005(-0.61,0.60)$ & 0.986 & $-0.05(-0.71,0.61)$ & 0.880 \\
Sample size & $0.15(-0.41,0.73)$ & 0.586 & $-1.81(-0.99,0.63)$ & 0.658 \\
Journal impact factor & $0.33(-0.24,0.91)$ & 0.258 & $0.23(-0.39,0.85)$ & 0.461 \\
\hline
\end{tabular}

SGAs: subgroup analyses, Cl: confidence interval.

\section{DISCUSSION}

\section{Summary and interpretation of findings}

In this methodological study, we assessed the quality and credibility of SGAs performed in CNCP trials published between 2012 and 2018. SGAs aim to detect a subset of the patient population with improved efficacy when compared to the whole trial population, based on specific patients or intervention characteristics. Of the 66 included studies that reported at least one SGA, a higher proportion of the included studies was industry-funded, indicating that a higher proportion of industry-funded trials reported an SGA compared to non-industry funded trials.

Another variable influencing the quality of SGAs is sample size. Lachenbruch [16] suggested a simple method of calculating a trial's sample size for it to be eligible to test for subgroup interactions using the contrast(s) for the interaction and a normal distribution. A required sample size of approximately 500 has also suggested by previous studies [17]. Based on these two rationales, $79 \%$ of the included studies did not meet the requirements and were considerably underpowered to detect any significant subgroup effects. This issue highlights the lack of power for performing SGAs.

The quality of SGAs is also influenced by the number of the subgroup hypotheses that were tested. In this study, approximately two-thirds of the included studies performed only one SGA and $7.5 \%$ of the studies performed more than 5 SGAs, leading them to exceed the quality criterion that less than 5 subgroup hypotheses should be tested. Performing many interaction tests in one study could suggest a significant inflation of type I error, which could enhance the probability of reporting spurious results.

Additionally, in slightly less than $50 \%$ of the studies, the authors expressed that they undertook an interaction test for analyzing subgroups, and reported a $P$ value for interaction. A test for interaction, which examines if the treatment effect varies across subgroup categories, is the only reliable statistical approach to claim that the existing difference between subgroups cannot be explained by chance $[10,18]$.

Overall, the quality of SGAs performed in the 66 included studies was low. Among the 177 SGAs identified, the quality of only $15(8.5 \%)$ was high. Of the 30 SGAs that claimed a subgroup effect using an appropriate test for interaction, the credibility of only 5 SGAs was evaluated as high. According to Table 3, approximately two-thirds of the SGAs claiming a subgroup effect failed to clearly indicate an a priori hypothesis for the subgroup effect. Even when subgroup effects were hypothesized a priori, the direction of a majority of subgroup effects (83\%) was not correctly hypothesized a priori. One reason for this could be about that $56 \%$ of the included studies were post-hoc analyses of RCTs. This result may be explained by the fact that these SGAs were carried out to find significant differences in primary outcome measures in specific patient subgroups when one was not found in an analysis of the whole study population. However, this study did not correlate this parameter of SGA quality with the primary outcome results for the whole study populations of the $44 \%$ of studies that did not generate a priori hypotheses. As such, this remains a hypothesis that warrants further study.

Nevertheless, of the studies which performed a test for interaction between subgroups, $90 \%$ of them satisfied this criterion that "the subgroup variable was a characteristic that was measured at baseline". This indicates that most of the SGAs were selected based on characteristics at baseline.

Overall, the results of this study indicate that a total of 52 SGAs reported a subgroup effect. However, in 22 of these subgroup effects, the authors concluded that there was a subgroup effect by reporting a significant treatment effect in one subgroup or by looking for significance in each subgroup separately which cannot be considered as a correct method of claiming a subgroup effect [18].

Independence of the interaction is an important criterion whose fulfillment in performing SGAs can increase the credibility of subgroup effects. When a study tests multiple hypotheses, the analyses might produce more than one significant interaction which might be associated with each other and explained by a common factor [10]. This is- 
sue can be addressed by including all significant and nonsignificant interactions in the regression model to see if the interaction terms are still significant. In our study, of the 30 claims, $14(46.7 \%)$ met this criterion by performing regression models to check if the interaction term was independent.

\section{Strengths and limitations of the study}

To our knowledge, the current study is the first methodological review conducted to assess the quality of SGAs among all non-cancer chronic pain trials after the publication of the 10 criteria to assess SGA validity in 2012 [4]. There is just one similar review [8]; however, our study differs in two important regards. Firstly, our study evaluated the quality of SGAs reported in all non-cancer chronic pain trials while the scope of the previous review was narrower and included specifically low back pain trials with SGAs. Secondly, our study assessed the quality and the credibility of all SGAs reported (positive and negative) rather than just looking at those with a claim of a subgroup effect. As such, we deem our review of the literature to be more robust.

Furthermore, given the variety of studies with different forms of SGAs, we divided the SGAs into 4 categories based on the test of interaction performed and the result of the SGAs (positive-negative) and evaluated the quality or credibility of each subgroup based on the number of criteria applied in each category. The previously available tools were designed to assess the credibility of subgroup effects claimed in the RCTs; however, there was no standard tool to take into consideration the quality of performing all SGAs rather than only those which reported a claim. As such, our approach allowed for a more stratified and appropriate evaluation of the SGAs performed.

Our study is also presented with two limitations. Firstly, based on the initial study protocol, we searched MEDLINE starting with 2013. Due to not obtaining the required sample size (60), we expanded our search to EMBASE and to the year 2012 to obtain more eligible studies. Since we limited the literature search to studies published in or after 2012 to coincide with the publication of the guidelines created by Sun et al. [4] and for it to thus have been possible for the SGAs to have been designed in accordance to those guidelines, we were only able to include 66 RCTs.

The results of our study are consistent with the findings of previous studies conducted on this issue [8]. Previous searches of the literature have also demonstrated the poor quality of SGAs and the low credibility of subgroup claims.

Contrary to what we expected, no significant association was found between the quality of SGAs, and the risk of bias, the source of funding, the sample size, or the journal impact factor. This finding indicates that the quality of SGAs might not be affected by study characteristics. One reason for this could be the small sample size which might have made our study underpowered to reach actual associations between study variables. Other studies have also reported a lack of association between study characteristics and SGA quality $[8,17]$. However, the source of funding was not a study characteristic included in the previous multivariable regressions published in the literature.

The results of the current study, in keeping with the results of previous studies $[19,20]$ show that a larger proportion of included trials were funded by industry. It is possible that this result indicates that, in the presence of non-significant results ( $73 \%$ vs. $27 \%$ in our study), industry funded trials may be more likely to attempt to seek statistically significant findings in patient subgroups. However, our multiple regression analyses did not prove this claim.

\section{Conclusion}

The findings of this study indicated that the overall quality of SGAs and the credibility of subgroup effects in CNCP trials is low. This study emphasizes the importance of utilizing appropriate scientific methodology to investigate subgroup effects and highlights the following issues: Those conducting trials should utilize the standardized criteria, specifically in the process of trial planning. Utilizing experienced statisticians to include SGAs in the analyses planning is highly recommended. Journal editors should also consider the developed criteria to assess the credibility of subgroup claims reported in the submitted manuscripts. Finally, knowledge users should also take caution in their interpretation of the results of SGAs and their application of the treatment in question to specific subpopulations.

\section{CONFLICT OF INTEREST}

No potential conflict of interest relevant to this article was reported.

\section{FUNDING}

No funding to declare.

\section{ORCID}

Mahmood AminiLari, https://orcid.org/0000-0002-0517-9666 Vahid Ashoorian, https://orcid.org/0000-0001-9225-155X

Alexa Caldwell, https://orcid.org/0000-0002-0223-6303 
Yasir Rahman, https://orcid.org/0000-0002-2817-3638

Robby Nieuwlaat, https://orcid.org/0000-0002-5267-7748

Jason W. Busse, https://orcid.org/0000-0002-0178-8712

Lawrence Mbuagbaw, https://orcid.org/0000-0001-5855-5461

\section{REFERENCES}

1. Ospina M, Harstall C. Prevalence of chronic pain: an overview. Edmonton, Alberta Heritage Foundation for Medical Research. 2002.

2. Elzahaf RA, Tashani OA, Unsworth BA, Johnson MI. The prevalence of chronic pain with an analysis of countries with a Human Development Index less than 0.9: a systematic review without meta-analysis. Curr Med Res Opin 2012; 28: 1221-9.

3. Venekamp RP, Rovers MM, Hoes AW, Knol MJ. Subgroup analysis in randomized controlled trials appeared to be dependent on whether relative or absolute effect measures were used. J Clin Epidemiol 2014; 67: 410-5.

4. Sun X, Briel M, Busse JW, You JJ, Akl EA, Mejza F, et al. Credibility of claims of subgroup effects in randomised controlled trials: systematic review. BMJ 2012; 344: el553.

5. Varadhan R, Wang SJ. Standardization for subgroup analysis in randomized controlled trials. J Biopharm Stat 2014; 24: 154-67.

6. Byth K, Gebski V. Factorial designs: a graphical aid for choosing study designs accounting for interaction. Clin Trials 2004; 1: 315-25.

7. McCormack R, Lamontagne M, Vannabouathong C, Deakon RT, Belzile EL. Comparison of the 3 different injection techniques used in a randomized controlled study evaluating a cross-linked sodium hyaluronate combined with triamcinolone hexacetonide (Cingal) for osteoarthritis of the knee: a subgroup analysis. Clin Med Insights Arthritis Musculoskelet Disord 2017; 10: 1179544117725026.

8. Saragiotto BT, Maher CG, Moseley AM, Yamato TP, Koes BW, Sun $\mathrm{X}$, et al. A systematic review reveals that the credibility of subgroup claims in low back pain trials was low. J Clin
Epidemiol 2016; 79: 3-9.

9. Oxman AD, Guyatt GH. A consumer's guide to subgroup analyses. Ann Intern Med 1992; 116: 78-84.

10. Sun X, Briel M, Walter SD, Guyatt GH. Is a subgroup effect believable? Updating criteria to evaluate the credibility of subgroup analyses. BMJ 2010; 340: c117.

11. Oxman A, Guyatt G, Cook D, Montori V. Summarizing the evidence. In: Users' guides to the medical literature: a manual for evidence-based clinical practice. Edited by Guyatt $G$, Rennie D. Chicago, AMA Press. 2002, pp 155-173.

12. Akl EA, Sun X, Busse JW, Johnston BC, Briel M, Mulla S, et al. Specific instructions for estimating unclearly reported blinding status in randomized trials were reliable and valid. J Clin Epidemiol 2012; 65: 262-7.

13. Hosmer DW, Lemeshow S. Goodness of fit tests for the multiple logistic regression model. Commun Stat Theory Methods 1980; 9: 1043-69.

14. Landis JR, Koch GG. The measurement of observer agreement for categorical data. Biometrics 1977; 33: 159-74.

15. Harris RJ, Quade D. The minimally important difference significant criterion for sample size. J Educ Stat 1992; 17: 27-49.

16. Lachenbruch PA. A note on sample size computation for testing interactions. Stat Med 1988; 7: 467-9.

17. Mistry D, Patel S, Hee SW, Stallard N, Underwood M. Evaluating the quality of subgroup analyses in randomized controlled trials of therapist-delivered interventions for nonspecific low back pain: a systematic review. Spine (Phila Pa 1976) 2014; 39: 618-29.

18. Rothwell PM. Treating individuals 2. Subgroup analysis in randomised controlled trials: importance, indications, and interpretation. Lancet 2005; 365: 176-86.

19. Sun X, Briel M, Busse JW, You JJ, Akl EA, Mejza F, et al. The influence of study characteristics on reporting of subgroup analyses in randomised controlled trials: systematic review. BMJ 2011; 342: d1569.

20. Barton S, Peckitt C, Sclafani F, Cunningham D, Chau I. The influence of industry sponsorship on the reporting of subgroup analyses within phase III randomised controlled trials in gastrointestinal oncology. Eur J Cancer 2015; 51: 2732-9. 


\section{Appendices}

\section{Appendix 1. Search strategy}

Database: Ovid MEDLINE epub ahead of print, in-process \& other non-indexed citations, Ovid MEDLINE(R) daily and Ovid MEDLINE(R) 1946 to present

\section{Search strategy:}

4

6

7

8

9

10

11

12

13

14

15

16

17

18

19

20

21

22

23

24

25

26

27

28

29

30

31

32

33

34

35

36

37

38

39

40

41

42

43

44

45

46

47

48

49

50 (chronic adj4 pain*).mp. (60364)

chronic pain/ (10418)

exp osteoarthritis/ (56304)

osteoarthrit*.mp. (78524)

osteo-arthritis.mp. (370)

degenerative arthrit*.mp. (1235)

exp rheumatoid arthritis/ (106226)

exp neuralgia/ (18213)

diabetic neuropathy/ (13813)

(neuropath* adj5 (pain* or diabet*)).mp. (38054)

neuralg*.mp. (24465)

zoster.mp. (19578)

irritable colon/ (6314)

(Irritable Bowel Syndrome or IBS).mp. (14170)

exp migraine/ (25156)

migraine.mp. (35284)

fibromyalgia/ (7739)

fibromyalg*.mp. (10571)

reflex sympathetic dystrophy.mp. (4041)

(complex regional pain syndromes or causalgia).mp. (2186)

intractable pain/ (6051)

phantom limb.mp. or agnosia/ or phantom pain/ or amputation stump/ (7218)

hyperalgesia/ (10385)

((noncancer* or non-cancer* or chronic* or recurrent or persist* or non-malign*) adj3 pain).mp. (17023)

or/1-24 (388401)

clinical trial/ (512199)

controlled study/ (0)

exp clinical study/ (859596)

randomized controlled trial/ (467803)

double blind procedure/ $(0)$

multicenter study/ (238803)

single blind procedure/ (0)

phase 3 clinical trial/ (0)

phase 4 clinical trial/ (0)

crossover procedure/ (0)

placebo/ (0)

allocat\$.mp. (203144)

assign\$.mp. (282136)

blind\$.mp. (332143)

(clinic\$ adj25 (study or trial)).mp. (1300807)

compar\$.mp. (5670215)

control\$.mp. (4869672)

cross?over.mp. (57020)

factorial\$.mp. (26363)

follow?up.mp. (19893)

placebo\$.mp. (211883)

prospectiv\$.mp. (767121)

random\$.mp. (1217036)

((singl\$ or doubl\$ or trebl\$ or tripl\$) adj25 (blind\$ or mask\$)).mp. (224239)

trial.mp. (1081277) 


$\begin{array}{ll}51 & \text { (versus or vs).mp. (1170229) } \\ 52 & \text { or/37-51 (10141777) } \\ 53 & \text { subgroup analysis.mp. (19173) } \\ 54 & \text { moderator.mp. (6154) } \\ 55 & \text { effect modifier.mp. (1963) } \\ 56 & \text { interaction.mp. (718086) } \\ 57 & \text { subpopulation.mp. (30080) } \\ 58 & \text { subset.mp. (140541) } \\ 59 & \text { or/53-58 (904752) } \\ 60 & \text { 25 and 52 and 59 (6034) } \\ 61 & \text { limit 60 to humans (4899) } \\ 62 & \text { limit 61 to yr="2012 -Current" (2133) }\end{array}$

Database: Embase <1996 to 2018 August 31>

Search strategy:

1 (chronic adj4 pain*) mp. (90141)

chronic pain/ (48559)

exp osteoarthritis/ (95666)

osteoarthrit*.mp. (106474)

osteo-arthritis.mp. (227)

degenerative arthrit*.mp. (958)

exp rheumatoid arthritis/ (137872)

exp neuralgia/ (78995)

diabetic neuropathy/ (17277)

(neuropath* adj5 (pain* or diabet*)).mp. (59624)

neuralg*.mp. (21562)

zoster.mp. (25946)

irritable colon/ (20767)

(Irritable Bowel Syndrome or IBS).mp. (20572)

exp migraine/ (47073)

migraine.mp. (51808)

fibromyalgia/ (16696)

fibromyalg*.mp. (17882)

reflex sympathetic dystrophy.mp. (1438)

(complex regional pain syndromes or causalgia).mp. (797)

intractable pain/ (3044)

phantom limb.mp. or agnosia/ or phantom pain/ or amputation stump/ (5403)

hyperalgesia/ (16796)

((noncancer* or non-cancer*or chronic* or recurrent or persist* or non-malign*) adj3 pain).mp. (21836)

or/1-24 (535124)

clinical trial/ (814030)

controlled study/ (5491827)

exp clinical study/ (6325695)

randomized controlled trial/ (464812)

double blind procedure/ (125723)

multicenter study/ (184132)

single blind procedure/ (30760)

phase 3 clinical trial/ (33715)

phase 4 clinical trial/ (2822)

crossover procedure/ (51817)

placebo/ (269065)

allocat\$.mp. (126145)

assign\$.mp. (299040)

blind\$.mp. (355535)

(clinic\$ adj25 (study or trial)).mp. (4549637) 


\begin{tabular}{|c|c|}
\hline 41 & compar\$.mp. (5803479) \\
\hline 42 & control\$.mp. (7892083) \\
\hline 43 & cross?over.mp. (73398) \\
\hline 44 & factorial\$.mp. (52978) \\
\hline 45 & follow?up.mp. (35513) \\
\hline 46 & placebo\$.mp. (338337) \\
\hline 47 & prospectiv\$.mp. (925030) \\
\hline 48 & random\$.mp. (1374029) \\
\hline 49 & ((singl\$ or doubl\$ or trebl\$ or tripl\$) adj25 (blind\$ or mask\$)).mp. (223919) \\
\hline 50 & trial.mp. (1676314) \\
\hline 51 & (versus or vs).mp. (1692991) \\
\hline 52 & or/37-51 (12375015) \\
\hline 53 & subgroup analysis.mp. (30202) \\
\hline 54 & moderator.mp. (6812) \\
\hline 55 & effect modifier.mp. (1092) \\
\hline 56 & subpopulation.mp. (76836) \\
\hline 57 & 53 or 54 or 55 or $56(114732)$ \\
\hline 58 & 25 and 52 and 57 (3096) \\
\hline 59 & limit 58 to human (2699) \\
\hline 60 & limit 59 to $y r=" 2012$-Current" (1779) \\
\hline
\end{tabular}


Appendix 2. Criteria to assess the credibility of subgroup claims [4]

Criterion Description of criteria Coding

Design

1. Is the subgroup variable a characteristic measured at baseline?

2. Was the subgroup variable a stratification factor at randomisation?

3. Was the hypothesis specified a priori?

4. Was the subgroup analysis one of small number of subgroup hypotheses tested $(\leq 5)$ ?

Analysis

5. Was the test of interaction significant (interaction $P<0.05$ )?

6. Was the significant interaction effect independent, if there were multiple significant interactions?
Subgroup variables measured after randomisation might be influenced by the tested interventions. The apparent difference of treatment effect between subgroups can be explained by the intervention, or by differing prognostic characteristics in subgroups that appear after randomisation.

Credibility of subgroup difference would be increased if a subgroup variable was also used for stratification at randomisation (i.e., stratified randomisation).

A subgroup analysis might be clearly planned before to test a hypothesis. This must be mentioned on the study protocol (registered or published) or primary trial, when appropriate. Post-hoc analyses are more susceptible to bias as well as spurious results and they should be viewed as hypothesis generating rather than hypothesis testing.

The greater the number of hypotheses tested, the greater the number of interactions that will be discovered by chance, that is, the more likely it is to make a type I error (reject one of the null hypotheses even if all are actually true). A more appropriate analysis would account for the number of subgroups.

Statistical tests of significance must be used to assess the likelihood that a given interaction might have arisen due to chance alone (the lower a $P$ value is, the less likely it is that the interaction can be explained by chance).

When testing multiple hypotheses in a single study, the analyses might yield more than one apparently significant interaction. These significant interactions might, however, be associated with each other, and thus explained by a common factor.
Yes, if the study specified that subgroups were defined on the basis of characteristics at baseline.

No, if the study describes that the subgroups were defined according to characteristics measured after randomisation or did not describe when the subgroups were defined.

Yes, if the randomisation included stratification based on the pre-specified subgroups variable.

No, if the study clearly reported information on stratification, but the subgroup variable of interest was not one of the stratification factors, or if no information was available regarding stratification.

Yes, there needs to be a publicly available record (i.e., study protocol, registry, or primary trial) of the hypothesis that predates the subgroup analyses.

No, if the report specifically says the analyses were post-hoc, or no information reported regarding this aspect.

Yes, if the authors clearly specify up to 5 subgroup hypotheses.

No, if authors clearly specified more than 5 subgroup hypotheses, or if the study did not give this information.

Yes, if the study used any reliable statistical test to assess the subgroup interactions (e.g., regression models), and a $P$ value lower than 0.05 .

No, no reliable statistical test used, or $P$ value higher than 0.05 .

Yes, if the significant subgroup effect was not associated with other significant interactions, or if the subgroup effect was tested regarding its independence with other interaction effects (usually tested in multivariable regression that includes interaction terms).

No, if the subgroup effect was analysed only as part of a significant interaction effect. 
Appendix 2. Continued

\begin{tabular}{ccc}
\hline Criterion & Description of criteria & Coding \\
\hline
\end{tabular}

\section{Context}

7. Was the direction of subgroup effect correctly pre-specified?

8. Was the subgroup effect consistent with evidence from previous studies?

9. Was the subgroup effect consistent across related outcomes?

10. Was there indirect evidence to support the apparent subgroup effect (biological rationale, laboratory tests, animal studies)?
A subgroup effect consistent with the prespecified direction will increase the credibility of a subgroup analysis. Failure to specify the direction or even getting the wrong direction weakens the case for a real underlying subgroup effect.

A hypothesis concerning differential response in a subgroup of patients may be generated by examination of data from a single study. The interaction becomes far more credible if it is also found in other similar studies. The extent to which a comprehensive scientific overview of the relevant literature finds an interaction to be consistently present is probably the best single index as to whether it should be believed. In other words, the replication of an interaction in independent, unbiased studies provides strong support for its believability.

The subgroup effect is more likely to be real if its effect manifest across all closely related outcomes. Studies must determine whether the subgroup effect existed among related outcomes.

We are generally more ready to believe a hypothesised interaction if indirect evidence makes the interaction more plausible. That is, to the extent that a hypothesis is consistent with our current understanding of the biologic mechanisms of disease, we are more likely to believe it. Such understanding comes from three types of indirect evidence: (i) from studies of different populations (including animal studies); (ii) from observations of interactions for similar interventions; and (iii) from results of studies of other related outcomes.
Yes, if the direction of subgroup effect was correctly specified a priori (e.g., study protocol, published statistical analysis plan, trial registry).

No, if the authors fail to specify the direction or specify the wrong direction a priori.

Yes, if the study provides information that there was a consistent interaction found in other studies consistent with both the power of the comparisons and differences between studies that might influence results.

No, if the information provided by the study was not consistent across other studies, or if no information about other studies were reported.

Yes, if there was a consistent interaction of a subgroup across closely related outcomes within the study; that is, there was a consistency of the subgroup effect across the related outcomes.

No, if the study did not determine whether the subgroup effect exists across the related outcomes.

Yes, if the study provides information that the consistent interaction of a subgroup is plausible to indirect evidence.

No, the significant interaction found was not reasonable with indirect evidence, or no information reported regarding this issue. 
Appendix 3. The summary of included studies

\begin{tabular}{|c|c|c|c|c|c|c|c|c|c|c|}
\hline $\begin{array}{l}\text { Study } \\
\text { ID }\end{array}$ & First author & Year & $\begin{array}{l}\text { Latest } \\
\text { impact } \\
\text { factor }\end{array}$ & Country & $\begin{array}{l}\text { Sample } \\
\text { size }\end{array}$ & Chief complaint & Intervention(s) & Comparator & Primary outcome measure & $\begin{array}{l}\text { Follow-up } \\
\text { duration } \\
\text { (days) }\end{array}$ \\
\hline 1 & Geusens & 2017 & 1.99 & Belgium & 211 & $\begin{array}{l}\text { Primary knee } \\
\text { osteoarthritis } \\
(\mathrm{OA})\end{array}$ & Choline-stabilized orthosilicic acid & Placebo & $\begin{array}{l}\text { Western Ontario and } \\
\text { McMaster Universities } \\
\text { Osteoarthritis Index } \\
\text { (WOMAC) pain }\end{array}$ & 84 \\
\hline 2 & Cook & 2015 & 3.02 & USA & 179 & $\begin{array}{r}\text { Chronic nonspe- } \\
\text { cific neck pain }\end{array}$ & Massage & $\begin{array}{l}\text { No additional } \\
\text { massage }\end{array}$ & Neck pain & 182 \\
\hline 3 & Smelt & 2012 & 6.2 & The Netherlands & 490 & Migraine & $\begin{array}{l}\text { Training on treating migraine and } \\
\text { participating patients invited } \\
\text { for a consultation/evaluation of } \\
\text { their therapy }\end{array}$ & Usual care & $\begin{array}{l}\text { Headache Impact Test } \\
\text { (HIT-6) }\end{array}$ & 365 \\
\hline 4 & Garcia & 2016 & 2.58 & Brazil & 140 & $\begin{array}{l}\text { Nonspecific low } \\
\text { back pain }\end{array}$ & $\begin{array}{l}\text { Mechanical diagnosis and } \\
\text { therapy }\end{array}$ & $\begin{array}{l}\text { Back School (a } \\
\text { group-based } \\
\text { treatment ap- } \\
\text { proach) }\end{array}$ & Pain intensity & 30 \\
\hline 5 & Arden & 2014 & 2.7 & $\begin{array}{l}\text { UK, Sweden, } \\
\text { and Germany }\end{array}$ & 218 & Knee pain & $\begin{array}{l}\text { A single IA injection in the study } \\
\text { knee of either NASHA (Duro- } \\
\text { lane } 60 \mathrm{mg} \text { in } 3 \mathrm{~mL} \text { ) }\end{array}$ & $\begin{array}{l}\text { Saline ( } 3 \mathrm{~mL} \\
\text { phosphate } \\
\text { buffered saline, } \\
\text { pH 7) }\end{array}$ & WOMAC pain & 42 \\
\hline 6 & Takamura & 2018 & 2.62 & Japan & 809 & Knee OA & $\begin{array}{l}\text { Gel-200 or phosphate buffered } \\
\text { saline }\end{array}$ & $\begin{array}{l}\text { Phosphate } \\
\text { buffered saline }\end{array}$ & WOMAC pain & 182 \\
\hline 7 & Aaron Yarlas & 2014 & 2.18 & USA & 541 & $\begin{array}{l}\text { Chronic low back } \\
\text { pain (CLBP) }\end{array}$ & $\begin{array}{l}\text { The Butrans (buprenorphine) } \\
\text { Transdermal System (BTDS) }\end{array}$ & $\begin{array}{l}\text { Matching pla- } \\
\text { cebo patch }\end{array}$ & Pain severity & 7 \\
\hline 8 & Marchettini & 2015 & 2.9 & Multi-Country & 804 & $\begin{array}{l}\text { Diabetic } \\
\text { peripheral } \\
\text { neuropathic } \\
\text { pain (DPNP) }\end{array}$ & $\begin{array}{l}\text { Duloxetine (60 mg/day) or prega- } \\
\text { balin (300 mg/day) }\end{array}$ & $\begin{array}{l}\text { Increasing each } \\
\text { drug to its } \\
\text { maximum dose }\end{array}$ & Pain intensity & 56 \\
\hline 9 & Castel & 2015 & 1.95 & Spain & 130 & Fibromyalgia & $\begin{array}{l}\text { Multidisciplinary treatment: } \\
\text { cognitive behavioural therapy } \\
\text { (CBT), and physical therapy }\end{array}$ & $\begin{array}{l}\text { Conventional } \\
\text { pharmacologic } \\
\text { treatment }\end{array}$ & $\begin{array}{l}\text { Pain intensity, functionality, } \\
\text { catastrophizing }\end{array}$ & 365 \\
\hline 10 & Broderick & 2016 & 5.59 & USA & 256 & $\begin{array}{l}\text { Chronic pain } \\
\text { due to OA of } \\
\text { the knee or } \\
\text { hip }\end{array}$ & Pain coping skills training & Usual care & Pain & 168 \\
\hline 11 & Tullo & 2012 & 2.28 & Italy & 107 & Migraine & Frovatriptan & $\begin{array}{l}\text { Zolmitriptan } 2.5 \\
\text { mg }\end{array}$ & Pain & 2 \\
\hline 12 & Monfort & 2014 & 3.3 & Spain & 100 & $\mathrm{OA}$ & $\begin{array}{l}\text { Ultrasound-guided intra-articular } \\
\text { treatment with hyaluronic acid }\end{array}$ & Betamethasone & $\begin{array}{l}\text { Clinical improvement by the } \\
\text { FIHOA score }\end{array}$ & 180 \\
\hline 13 & McCormack & 2017 & No IF & Canada & 368 & $\begin{array}{l}\text { Kellgren- } \\
\text { Lawrence (KL) } \\
\text { grade I-III knee } \\
\text { OA }\end{array}$ & Cingal & $\begin{array}{l}\text { Both Monovisc } \\
\text { and saline }\end{array}$ & WOMAC pain & 84 \\
\hline 14 & Jürg Schliessbach & 2018 & 2.76 & Switzerland & 50 & $\begin{array}{l}\text { Chronic low- } \\
\text { back pain }\end{array}$ & Imipramine 75 mg & Active placebo & Intensity of low-back pain & 0.08 \\
\hline 15 & Stamuli & 2012 & 2.73 & UK & 233 & $\begin{array}{l}\text { Irritable bowel } \\
\text { syndrome }\end{array}$ & $\begin{array}{l}\text { Short course of traditional acu- } \\
\text { puncture plus usual GP care }\end{array}$ & Usual GP care & $\begin{array}{l}\text { The EQ-5D to measure and } \\
\text { value patients' health } \\
\text { states }\end{array}$ & 365 \\
\hline 16 & R. Forestier & 2014 & No IF & France & 214 & Knee OA & $\begin{array}{l}\text { Crenobalneotherapy (spa) } \\
\text { therapy }\end{array}$ & $\begin{array}{l}\text { Exercises and } \\
\text { usual treat- } \\
\text { ment alone }\end{array}$ & WOMAC function subscale & 252 \\
\hline 17 & Duivenvoorden & 2015 & 4.09 & The Netherlands & 91 & $\begin{array}{l}\text { Symptomatic } \\
\text { medial com- } \\
\text { partmental } \\
\text { knee OA }\end{array}$ & A laterally wedged insole & Valgus brace & Pain severity & 42 \\
\hline 18 & Rikke K. Jensen & 2015 & No IF & Denmark & 96 & $\begin{array}{l}\text { Persistent low } \\
\text { back pain }\end{array}$ & $\begin{array}{l}\text { A new treatment approach com- } \\
\text { paring rest }\end{array}$ & Exercise group & Low back pain intensity & 426 \\
\hline 19 & Annemieke J.H & 2015 & 2.58 & The Netherlands & 135 & Sciatica & $\begin{array}{l}\text { Physical therapy plus general } \\
\text { practitioners' care }\end{array}$ & $\begin{array}{l}\text { General practitio- } \\
\text { ners' care alone }\end{array}$ & Leg pain intensity & 365 \\
\hline 20 & Kristen Radcliff & 2013 & 2.79 & USA & 501 & $\begin{array}{l}\text { Radicular pain } \\
\text { with positive } \\
\text { nerve root ten- } \\
\text { sion sign }\end{array}$ & $\begin{array}{l}\text { Surgical treatment (lumbar discec- } \\
\text { tomy) }\end{array}$ & $\begin{array}{l}\text { Nonoperative } \\
\text { treatment }\end{array}$ & $\begin{array}{l}\text { Bodily pain, physical } \\
\text { function, and mental } \\
\text { component summary } \\
\text { domains of the SF-36 }\end{array}$ & 730 \\
\hline
\end{tabular}


Appendix 3. Continued

\begin{tabular}{|c|c|c|c|c|c|c|c|c|c|c|}
\hline $\begin{array}{l}\text { Study } \\
\text { ID }\end{array}$ & First author & Year & $\begin{array}{l}\text { Latest } \\
\text { impact } \\
\text { factor }\end{array}$ & Country & $\begin{array}{l}\text { Sample } \\
\text { size }\end{array}$ & Chief complaint & Intervention(s) & Comparator & Primary outcome measure & $\begin{array}{l}\text { Follow-up } \\
\text { duration } \\
\text { (days) }\end{array}$ \\
\hline 21 & Tanenberg & 2013 & 2.18 & USA & 407 & DPNP & $\begin{array}{l}\text { The combination of duloxetine, } \\
60 \mathrm{mg} / \mathrm{d} \text {, and gabapentin, } \\
900 \mathrm{mg} / \mathrm{d} \text { or more duloxetine } \\
\text { monotherapy, } 60 \mathrm{mg} / \mathrm{d}\end{array}$ & $\begin{array}{l}\text { Pregabalin mono- } \\
\text { therapy }\end{array}$ & Daily pain & 84 \\
\hline 22 & Verbruggen & 2012 & 12.35 & Belgium & 60 & Erosive hand $\mathrm{OA}$ & 40 mg adalimumab & Placebo & $\begin{array}{l}\text { Reduction in progression of } \\
\text { structural damage }\end{array}$ & 365 \\
\hline 23 & Sumaiyah Mat & 2018 & 1.85 & Malaysia & 41 & Knee OA & $\begin{array}{l}\text { A home-based modified Otago } \\
\text { Exercise Program }\end{array}$ & $\begin{array}{l}\text { General health } \\
\text { advice and } \\
\text { conventional } \\
\text { treatment }\end{array}$ & $\begin{array}{l}\text { Fear of falling, OA symp- } \\
\text { toms, and functional } \\
\text { ability }\end{array}$ & 182 \\
\hline 24 & Ben-Ami & 2017 & 3.09 & Israel & 220 & CLBP & $\begin{array}{l}\text { Enhanced transtheoretical model } \\
\text { intervention }\end{array}$ & Physical therapy & Disability & 365 \\
\hline 25 & Bergström & 2012 & 2.04 & Sweden & 214 & $\begin{array}{l}\text { Patients with } \\
\text { chronic neck } \\
\text { pain }\end{array}$ & $\begin{array}{l}\text { Behavioural-oriented physio- } \\
\text { therapy (PT), CBT, behavioural } \\
\text { medicine rehabilitation (BM) }\end{array}$ & $\begin{array}{l}\text { Treatment-as- } \\
\text { usual }\end{array}$ & $\begin{array}{l}\text { Registered sickness } \\
\text { absence }\end{array}$ & 3,650 \\
\hline 26 & Kvalvaag & 2017 & 6.05 & Norway & 143 & $\begin{array}{l}\text { Subacro- } \\
\text { mial pain } \\
\text { syndrome }\end{array}$ & $\begin{array}{l}\text { Audial extracorporeal shock wave } \\
\text { therapy (reswt) in addition to } \\
\text { supervised exercises }\end{array}$ & $\begin{array}{l}\text { Sham rest in } \\
\text { addition to } \\
\text { supervised } \\
\text { exercises }\end{array}$ & Shoulder pain & 168 \\
\hline 27 & Brämberg & 2017 & 1.99 & Sweden & 159 & $\begin{array}{l}\text { Non-specific low } \\
\text { back pain }\end{array}$ & Kundalini yoga- strength training & $\begin{array}{l}\text { Self-care } \\
\text { evidence- } \\
\text { based advice }\end{array}$ & Sickness absenteeism & 365 \\
\hline 28 & Hahne & 2017 & 3.11 & Australia & 54 & $\begin{array}{l}\text { Clinical features } \\
\text { of radiculopa- } \\
\text { thy and imag- } \\
\text { ing showing } \\
\text { a lumbar disc } \\
\text { herniation }\end{array}$ & $\begin{array}{l}\text { Individualized functional restora- } \\
\text { tion incorporating advice }\end{array}$ & $\begin{array}{l}\text { Guideline-based } \\
\text { advice alone }\end{array}$ & $\begin{array}{l}\text { Activity limitation, back pain } \\
\text { and leg pain }\end{array}$ & 364 \\
\hline 29 & Kellner & 2012 & 2.7 & USA & 4,484 & $\begin{array}{l}\text { OA -rheumatoid } \\
\text { arthritis (RA) }\end{array}$ & Celecoxib & $\begin{array}{l}\text { Diclofenac SR } \\
\text { plus omepra- } \\
\text { zole }\end{array}$ & $\begin{array}{l}\text { A composite of clinically } \\
\text { significant upper and } \\
\text { lower gastrointestinal (GI) } \\
\text { events }\end{array}$ & 182 \\
\hline 30 & Ashina & 2018 & 3.88 & Denmark & 667 & $\begin{array}{l}\text { Chronic mi- } \\
\text { graine }\end{array}$ & $\begin{array}{l}\text { Monthly erenumab (70 mg or } \\
140 \mathrm{mg} \text { ) }\end{array}$ & Placebo & $\begin{array}{l}\text { Change in reduced monthly } \\
\text { migraine days }\end{array}$ & 90 \\
\hline 31 & Sarvajeet PAL & 2016 & 2.42 & India & 3,366 & RA & $\begin{array}{l}\text { Add-on subcutaneous golimumab } \\
\text { therapy }\end{array}$ & $\begin{array}{l}\text { Conventional } \\
\text { dmards regi- } \\
\text { men }\end{array}$ & $\begin{array}{l}\text { Proportion of patients } \\
\text { achieving good to moder- } \\
\text { ate DAS28-ESR }\end{array}$ & 182 \\
\hline 32 & Broglio & 2017 & 2.18 & USA & 922 & $\begin{array}{l}\text { Chronic non- } \\
\text { malignant and } \\
\text { nonneuro- } \\
\text { pathic } \\
\text { pain }\end{array}$ & Hydrocodone bitartrate (HYD) & Placebo & $\begin{array}{l}\text { Patient-reported pain } \\
\text { intensity }\end{array}$ & 365 \\
\hline 33 & Yiming MU & 2018 & 7.27 & China & 620 & $\begin{array}{l}\text { Painful diabetic } \\
\text { peripheral } \\
\text { neuropathy }\end{array}$ & 300 mg/day pregabalin & Placebo & Pain & 56 \\
\hline 34 & Tanaka & 2018 & 1.95 & Japan & 878 & RA & Sirukumab subcutaneously & Placebo & $\begin{array}{l}\text { The American College of } \\
\text { Rheumatology (ACR) } 20 \\
\text { response at week } 16\end{array}$ & 112 \\
\hline 35 & Genovese & 2015 & 1.97 & Multi-Country & 1,004 & RA & $\begin{array}{l}\text { Tabalumab every } 4 \text { weeks (120/ } \\
\text { Q4W), } 90 \text { mg tabalumab every } \\
2 \text { weeks (90/Q2W) }\end{array}$ & Placebo & $\begin{array}{l}\text { ACR } 20 \text { ( } 20 \% \text { improvement } \\
\text { in American College of } \\
\text { Rheumatology criteria) } \\
\text { response at week } 24\end{array}$ & 168 \\
\hline 36 & Palacios & 2016 & 2.67 & Mexico & 7,492 & Osteoporosis & $\begin{array}{l}\text { Bazedoxifene (BZA) } 20 \mathrm{mg} / \mathrm{d} \text {, } \\
\text { BZA } 40 \mathrm{mg} / \mathrm{d} \text {, raloxifene } 60 \\
\mathrm{mg} / \mathrm{d}\end{array}$ & Placebo & $\begin{array}{l}\text { Serum concentrations of } \\
\text { osteocalcin }\end{array}$ & 1,095 \\
\hline 37 & Mease & 2014 & 2.58 & USA & 336 & Fibromyalgia & Milnacipran (MLN) & Placebo & Pain & 365 \\
\hline 38 & Zheng & 2016 & 2.02 & China & 448 & $\begin{array}{l}\text { Irritable bowel } \\
\text { syndrome }\end{array}$ & The electroacupuncture & $\begin{array}{l}\text { Loperamide } \\
\text { group }\end{array}$ & Stool frequency & 28 \\
\hline 39 & Bartolini & 2012 & 3.34 & Italy & 114 & Migraine & Frovatriptan $2.5 \mathrm{mg}$ & $\begin{array}{l}\text { Almotriptan } 12.5 \\
\text { mg }\end{array}$ & $\begin{array}{l}\text { The proportion of pain-relief } \\
\text { episodes }\end{array}$ & 2 \\
\hline
\end{tabular}


Appendix 3. Continued

\begin{tabular}{|c|c|c|c|c|c|c|c|c|c|c|}
\hline $\begin{array}{l}\text { Study } \\
\text { ID }\end{array}$ & First author & Year & $\begin{array}{l}\text { Latest } \\
\text { impact } \\
\text { factor }\end{array}$ & Country & $\begin{array}{l}\text { Sample } \\
\text { size }\end{array}$ & Chief complaint & Intervention(s) & Comparator & Primary outcome measure & $\begin{array}{l}\text { Follow-up } \\
\text { duration } \\
\text { (days) }\end{array}$ \\
\hline 40 & Kanzaki & 2015 & 2.5 & Japan & 100 & Knee pain & $\begin{array}{l}\text { 1,200 mg of glucosamine } \\
\text { hydrochloride, } 60 \mathrm{mg} \text { of chon- } \\
\text { droitin sulfate, } 45 \mathrm{mg} \text { of type } \\
\text { Il collagen peptides, } 90 \mathrm{mg} \text { of } \\
\text { quercetin glycosides, } 10 \mathrm{mg} \text { of } \\
\text { imidazole peptides, and } 5 \mu \mathrm{g} \\
\text { of vitamin D per day }\end{array}$ & Placebo & Knee-joint functions & 112 \\
\hline 41 & Chan & 2017 & 3.12 & Australia & 96 & $\begin{array}{l}\text { Non-reducible } \\
\text { discogenic } \\
\text { pain (NRDP) }\end{array}$ & $\begin{array}{l}\text { Individualized functional restora- } \\
\text { tion plus guideline-based } \\
\text { advice }\end{array}$ & Advice alone & Disability back and leg pain & 182 \\
\hline 42 & Thackeray & 2016 & 3.09 & USA & 120 & $\begin{array}{l}\text { Low back pain } \\
\text { and nerve root } \\
\text { compression }\end{array}$ & $\begin{array}{l}\text { Physical therapy following an } \\
\text { extension-oriented treatment } \\
\text { approach with the addition of } \\
\text { mechanical traction }\end{array}$ & $\begin{array}{l}\text { Physical therapy } \\
\text { without the } \\
\text { addition of } \\
\text { mechanical } \\
\text { traction }\end{array}$ & $\begin{array}{l}\text { Low back pain-related dis- } \\
\text { ability }\end{array}$ & 365 \\
\hline 43 & Bennell & 2015 & 4.14 & Australia & 100 & Medial knee OA & $\begin{array}{l}\text { Exercise programs quadriceps } \\
\text { strengthening }\end{array}$ & $\begin{array}{l}\text { Neuromuscular } \\
\text { exercise (NEXA) }\end{array}$ & Overall knee pain & 365 \\
\hline 44 & Baratloo & 2016 & 0.8 & Iran & 110 & $\begin{array}{l}\text { Migraine head- } \\
\text { aches }\end{array}$ & Caffeine versus ketorolac & Ketorolac & Pain intensity & 0.08 \\
\hline 45 & Knoop & 2014 & 1.82 & The Netherlands & 159 & $\begin{array}{l}\text { Knee OA and } \\
\text { knee instabil- } \\
\text { ity }\end{array}$ & $\begin{array}{l}\text { Knee stabilization therapy, prior } \\
\text { to strength/functional training }\end{array}$ & $\begin{array}{l}\text { Exercise program } \\
\text { without knee } \\
\text { stabilization } \\
\text { therapy }\end{array}$ & $\begin{array}{l}\text { WOMAC subscale physical } \\
\text { function }\end{array}$ & 266 \\
\hline 46 & Haufe & 2017 & 2.76 & Germany & 226 & Low back pain & $\begin{array}{l}\text { 5-month non-supervised training } \\
\text { at home }\end{array}$ & Wait-list-control & $\begin{array}{l}\text { Isometric back extension } \\
\text { strength associated with } \\
\text { low back pain disability } \\
\text { and function }\end{array}$ & 140 \\
\hline 47 & Garcia & 2018 & 7.86 & Brazil & 148 & CLBP & $\begin{array}{c}\text { Mckenzie Method of Mechanical } \\
\text { Diagnosis and Therapy (MDT) }\end{array}$ & Placebo & Pain intensity and disability & 365 \\
\hline 48 & Weegen & 2015 & 3.33 & The Netherlands & 196 & $\begin{array}{l}\text { Symptomatic } \\
\text { knee OA }\end{array}$ & $\begin{array}{l}\text { A specific brand of hyaluronic } \\
\text { acid }\end{array}$ & Placebo & $\begin{array}{l}\text { Range of motion (ROM), } \\
\text { pain }\end{array}$ & 182 \\
\hline 49 & Aurora SK & 2014 & 3.12 & USA & 1,384 & Migraine & Onabotulinumtoxina (155 U) & Placebo & Frequency of headache & 168 \\
\hline 50 & Amerongen & 2017 & 3.18 & The Netherlands & 24 & $\begin{array}{l}\text { Progressive } \\
\text { primary or } \\
\text { secondary MS }\end{array}$ & $\begin{array}{l}\text { Oral formulation of D9-Tetrahy- } \\
\text { drocannabinol }\end{array}$ & Placebo & Objective spasticity & 28 \\
\hline 51 & Losina & 2016 & 4.14 & USA & 308 & $\begin{array}{l}\text { Total knee } \\
\text { arthroplasty } \\
\text { (TKA) }\end{array}$ & $\begin{array}{l}\text { Postoperative care with frequent } \\
\text { follow-up by a care navigator }\end{array}$ & Usual care & WOMAC physical function & 182 \\
\hline 52 & Petersen & 2015 & 1.99 & Denmark & 350 & CLBP & The Mckenzie method or MDT & $\begin{array}{l}\text { Spinal manipula- } \\
\text { tion treatment }\end{array}$ & Disability & 60 \\
\hline 53 & Amris & 2016 & 1.8 & Denmark & 191 & $\begin{array}{l}\text { Fibromyalgia } \\
\text { and chronic } \\
\text { widespread } \\
\text { pain (CWP) }\end{array}$ & $\begin{array}{l}\text { Group-based multi-component } \\
\text { rehabilitation program }\end{array}$ & Waiting list & Motor and process skills & 182 \\
\hline 54 & Licciardone & 2013 & $\begin{array}{l}\text { Not } \\
\text { found }\end{array}$ & USA & 144 & Low back pain & $\begin{array}{l}\text { Usual obstetric care and osteo- } \\
\text { pathic manipulative treatment } \\
\text { (UOBC + OMT), usual obstetric } \\
\text { care and sham ultrasound } \\
\text { therapy (UOBC + SUT) }\end{array}$ & UOBC & $\begin{array}{l}\text { Progressive back-specific } \\
\text { dysfunction }\end{array}$ & 63 \\
\hline 55 & Cook & 2015 & 3.1 & USA & 191 & $\begin{array}{l}\text { Chronic non- } \\
\text { specific neck } \\
\text { pain }\end{array}$ & Massage & $\begin{array}{l}\text { A wait-list control } \\
\text { group }\end{array}$ & Neck pain & 182 \\
\hline 56 & Licciardone & 2016 & 0.7 & USA & 455 & CLBP & A short regimen of OMT & Sham-controlled & LBP intensity & 84 \\
\hline 57 & Overdevest & 2014 & 3.19 & The Netherlands & 283 & $\begin{array}{l}\text { Sciatica due to } \\
\text { a lumbar disc } \\
\text { herniation }\end{array}$ & Surgery & $\begin{array}{l}\text { Prolonged } \\
\text { conservative } \\
\text { treatment }\end{array}$ & Recovery of motor deficit & 364 \\
\hline 58 & Price & 2017 & 3.2 & Canada & 70 & $\begin{array}{c}\text { Postherpetic } \\
\text { neuralgia }\end{array}$ & Tv-45070 & $\begin{array}{l}\text { Placebo oint- } \\
\text { ments }\end{array}$ & Pain intensity & 21 \\
\hline
\end{tabular}


Appendix 3. Continued

\begin{tabular}{|c|c|c|c|c|c|c|c|c|c|c|}
\hline $\begin{array}{l}\text { Study } \\
\text { ID }\end{array}$ & First author & Year & $\begin{array}{l}\text { Latest } \\
\text { impact } \\
\text { factor }\end{array}$ & Country & $\begin{array}{l}\text { Sample } \\
\text { size }\end{array}$ & Chief complaint & Intervention(s) & Comparator & Primary outcome measure & $\begin{array}{l}\text { Follow-up } \\
\text { duration } \\
\text { (days) }\end{array}$ \\
\hline 59 & Kwon & 2013 & 2.84 & USA & 300 & $\begin{array}{l}\text { Pain associ- } \\
\text { ated with } \\
\text { glenohumeral } \\
\text { osteoarthritis } \\
\text { (GH-OA) }\end{array}$ & Sodium hyaluronate $(\mathrm{HA})$ & $\begin{array}{l}\text { Phosphate- } \\
\text { buffered saline } \\
\text { (PBS) }\end{array}$ & Pain & 182 \\
\hline 60 & Kessler & 2014 & 2.76 & Switzerland & 60 & $\begin{array}{l}\text { Chronic pelvic } \\
\text { pain syn- } \\
\text { drome (cpps) }\end{array}$ & Sono-electro-magnetic therapy & Placebo & $\begin{array}{l}\text { A change in the national in- } \\
\text { stitutes of health chronic } \\
\text { prostatitis symptom index }\end{array}$ & 84 \\
\hline 61 & Jensen & 2015 & 1.95 & USA & 25 & Chronic pain & $\begin{array}{l}\text { Consumption of hydrolyzed water- } \\
\text { soluble egg membrane }\end{array}$ & Placebo & ROM, pain at rest & 28 \\
\hline 62 & Mohs & 2012 & 3.81 & USA & 154 & Fibromyalgia & Duloxetine & Placebo & $\begin{array}{l}\text { Speed of processing on } \\
\text { tasks requiring visual at- } \\
\text { tention, working memory, } \\
\text { and executive function }\end{array}$ & 84 \\
\hline 63 & McGuire & 2014 & 3.11 & USA & 749 & $\begin{array}{l}\text { Lumbar pathol- } \\
\text { ogy }\end{array}$ & $\begin{array}{l}\text { Operative versus nonoperative } \\
\text { treatments }\end{array}$ & $\begin{array}{r}\text { Nonoperative } \\
\text { treatments }\end{array}$ & $\begin{array}{l}\text { The components of the SF- } \\
36\end{array}$ & 730 \\
\hline 64 & Enomoto & 2018 & 1.21 & Japan & 353 & $\begin{array}{l}\text { Patients with } \\
\text { knee OA pain }\end{array}$ & Duloxetine & Placebo & Pain & 98 \\
\hline 65 & Schlögl & 2018 & 5.32 & Switzerland & 200 & Chronic pain & Vitamin D & $\begin{array}{l}\text { Combination of } \\
\text { calcifediol and } \\
\text { vitamin D3 }\end{array}$ & $\begin{array}{l}\text { Change in the mean num- } \\
\text { ber of painful areas }\end{array}$ & 365 \\
\hline 66 & Mecklenburg & 2018 & 4.67 & USA & 162 & $\begin{array}{l}\text { Chronic knee } \\
\text { pain }\end{array}$ & $\begin{array}{l}\text { A remotely delivered, home- } \\
\text { based } 12 \text {-week intervention } \\
\text { program }\end{array}$ & $\begin{array}{l}\text { Three education } \\
\text { pieces }\end{array}$ & $\begin{array}{l}\text { Knee injury and } \mathrm{OA} \\
\text { outcome score pain } \\
\text { subscale }\end{array}$ & 84 \\
\hline
\end{tabular}

IA: intra-articular, NASHA: non-animal stabilized hyaluronic acid, FIHOA: Functional Index of Hand Osteoarthritis, GP: General Practitioner, EQ-5D: EuroQol five-dimension scale, SF-36: the 36-Item Short Form Health Survey, SR: slow release, DAS28-ESR: Disease Activity Score 28-joint count - erythrocyte sedimentation rate, MS: multiple sclerosis. 